\title{
WITOLD KULA (1916-1988). SZKIC DO PORTRETU
}

Streszczenie. Witold Kula należy bez wątpienia do wąskiej elity dziejopisów epoki Polski Ludowej, jest także najbardziej rozpoznawanym jej przedstawicielem na arenie międzynarodowej. Niniejszy tekst stawia sobie za cel przybliżenie najważniejszych momentów jego biografii, krótką charakterystykę dorobku oraz jego recepcji we współczesnej historiografii.

Słowa kluczowe: prof. Witold Kula, XX w., zarys biografii, recepcja dorobku naukowego

W itold Kula należy bez wątpienia do wąskiej elity dziejopisów epoki Polski Ludowej, jest także najbardziej rozpoznawanym jej przedstawicielem na arenie międzynarodowej ${ }^{1}$. W redagowanej przez Kelly'ego Boyda Encyklopedia of Historians and Historical Writing (1999) znalazło się miejsce jedynie dla trzech polskich badaczy - Joachima Lelewela, Witolda Kuli i Oskara Haleckiego. Autor biogramu we wspomnianej encyklopedii - Lee Blackwood podkreślił, że dorobek W. Kuli świadczy o wysokich standardach obowiązujących w historiografii PRL, oraz zwrócił uwagę na wpływ koncepcji polskiego historyka na twórczość takich badaczy jak Eric Hobsbawm czy Immanuel Wallerstein ${ }^{2}$. Z kolei w niedawno opublikowanej A Concise History of History. Global Historiography from Antiquity to the Present Daniela Woolfa (najnowsze

* Uniwersytet Łódzki, Wydział Filozoficzno-Historyczny, Instytut Historii, Katedra Historii Historiografii i Nauk Pomocniczych Historii, e-mail: rafal.stobiecki@uni.lodz.pl.

${ }^{1}$ W niniejszym artykule odwołuję się i częściowo powtarzam swoje uwagi z tekstu Witold Kula (1916-1988). Historyk zaplątany w historię, [w:] tenże, Historycy polscy wobec wyzwań XX wieku, Poznań 2014, s. 273-306. Tamże bogaty wybór literatury przedmiotu. Z nowszych wypowiedzi na temat W. Kuli warto odnotować pracę syna - Marcina Kuli, Jerzy Jedlicki historyk nietypowy, Warszawa 2018 (tam liczne fragmenty korespondencji W. Kuli z bohaterem książki). Bibliografia prac W. Kuli za lata 1935-1990, zestawiona przez R. Czepulis-Rastenis została opublikowana w zbiorze Dziedzictwo Witolda Kuli, Warszawa 1990. Przedruk wraz z uzupełnieniami dokonanymi przez M. Kulę w Rozdziatkach.

${ }^{2}$ L. Blackwood, Witold Kula 1916-1988, [w:] Encyklopedia of Historians and Historical Writing, ed. K. Boyd, London-Chicago 1999, s. 670. 
wydanie 2019) wymieniono dwóch polskich dziejopisów - wspomnianych już Lelewela i właśnie Kulę. Dorobek warszawskiego historyka doceniony został także w jeszcze jednej anglojęzycznej syntezie, mianowicie w wielotomowej The Oxford History of Historical Writing. W. Kula pojawia się w niej obok innych prominentnych postaci polskiej historiografii okresu powojennego, takich jak: Bronisław Geremek, Aleksander Gieysztor, Tadeusz Manteuffel, Marian Małowist, Zygmunt Wojciechowski czy Andrzej Wyczański³

Międzynarodową sławę zapewniła mu opublikowana w 1962 r. Teoria ekonomiczna ustroju feudalnego. Próba modelu, mająca swoje wydania m.in.: angielskie, włoskie, hiszpańskie, portugalskie i węgierskie. Do edycji angielskiej i francuskiej, co wielce charakterystyczne, wstęp pisał sam Fernand Braudel, historyk - instytucja, jeden z koryfeuszy historiografii XX w., spod znaku Annales.

Witold Kula urodził się w Warszawie 18 maja 1916 r. Studiował historię i socjologię jako przedmiot poboczny w Uniwersytecie Warszawskim (UW) oraz ekonomię w Wolnej Wszechnicy Polskiej (WWP). Do grona swoich mistrzów, w pisanym ex post tekście z okazji jubileuszu w 1976 r., zaliczył: Stanisława Arnolda, Natalię Gąsiorowską, Stefana Czarnowskiego i Zdzisława Zmidrygiera-Konopkę ${ }^{4}$. To zestawienie nie wydaje się przypadkowe. Wszyscy oni reprezentowali inną wizję historii niż ta, która dominowała na ówczesnych uniwersytetach. S. Arnold i N. Gąsiorowska specjalizowali się w historii gospodarczej, Z. Zmidrygier-Konopka, badacz starożytności, w studiach nad ustrojem rzymskim próbował ukazywać go na szerszym tle społecznym. Socjolog Stefan Czarnowski powszechnie uznawany jest za jednego z twórców polskich badań na historią mentalności czy wyobrażeń społecznych. Jak wspominał W. Kula, wybór historii gospodarczej był w pełni świadomy i był wyborem dokonanym „przeciw”:

przeciwko szkolnej wersji historii, wersji przesłodzonej, ckliwej, solidarystycznej, nacjonalistycznej. Szukałem historii chłopów i robotników, rolnictwa i przemysłu, szukałem historii ludzi skromnych i nieznanych, których zbiorowa praca, ofiary, cierpienia, stworzyły kraj jakim jest ${ }^{5}$.

Od 1937 r. W. Kula pracował jako asystent-wolontariusz w WWP, przy katedrze kierowanej przez N. Gąsiorowską. W 1939 r. uzyskał doktorat na UW na podstawie pracy Demografia Królestwa Polskiego w XIX w. (niedrukowana), napisany pod kierunkiem Stanisława Arnolda.

${ }^{3}$ M. Górny, Historical Writing in Poland, Czechoslovakia, and Hungary, [w:] The Oxford History of Historical Writing, ed. by A. Schneider and D. Woolf, vol. 5, Oxford 2015, s. 243-265.

${ }^{4}$ W. Kula, Moja edukacja sentymentalna, [w:] idem, Wokót historii, Warszawa 1988, s. 455.

${ }^{5}$ Ibidem. 
Już pod koniec lat trzydziestych, W. Kula zbliżył się do środowisk intelektualnych komunizującej lewicy. Odrzucały one rzeczywistość Polski przedwrześniowej, krytycznie odnosiły się do tej wersji tradycji polskiej, która kojarzona była z klerykalizmem, nacjonalizmem i antysemityzmem. Choć po wybuchu wojny związki te zostały osłabione, pozostawiły jednak, jak można przypuszczać, trwały ślad w osobowości bohatera niniejszego szkicu.

Podczas okupacji W. Kula związał się z Biurem Informacji Propagandy Komendy Głównej Armii Krajowej, używał pseudonimów „Żakowski” i „Bułhak". Do konspiracji wciągnął go przyjaciel, też historyk - Ludwik Widerszal. W. Kula pracował w Wydziale Informacji BIP, kierowanym przez Jerzego Makowieckiego. W strukturze tej działali także inni historycy m.in.: Aleksander Gieysztor i Stanisław Herbst. Ponadto pod kierunkiem Aleksandra Kamińskiego redagował „Biuletyn Informacyjny”. Jednocześnie bohater niniejszego szkicu brał udział w tajnym nauczaniu w ramach konspiracyjnej Wolnej Wszechnicy Polskiej, kierowanej przez N. Gąsiorowską. Wykładał historię młodym ludziom, którzy związani byli z Batalionami Chłopskimi. Studia te organizowała, późniejsza profesor Uniwersytetu Łódzkiego - Helena Brodowska. W. Kula uczestniczył w Powstaniu Warszawskim, po klęsce dostał się do niemieckiego obozu jenieckiego w Gross-Born II D.

Jak można przypuszczać, nie miał dylematów - wracać czy pozostać poza krajem? Decydowały względy zarówno rodzinne (w kraju pozostał mały syn - Marcin), jak też polityczne.

Po wojnie W. Kula związał się początkowo z Uniwersytetem Łódzkim (UŁ). W latach 1945-1947 pracował jako adiunkt, a następnie jako docent, w Katedrze Historii Społeczno-Gospodarczej, kierowanej przez N. Gąsiorowską. Pomagał w gromadzeniu zbiorów późniejszej biblioteki Instytutu Historii UŁ. Publikował na łamach wychodzących w Łodzi pism lewicowych - „Kuźnicy” i „Myśli Współczesnej”. Żywo uczestniczył w dokonującym się wówczas, w pierwszych latach powojennych, procesie reorientacji polskiego dziejopisarstwa. Krytykował tradycyjną historiografię i jej kościec - historię polityczną. Remedium na słabości przedwojennego dziejopisarstwa dostrzegał w otwarciu się historii na inne dziedziny wiedzy, przede wszystkim ekonomię i socjologię. W programowym artykule Uwagi o historii gospodarczej drukowanym w „Kuźnicy”, W. Kula dostrzegał w tej dyscyplinie zarówno walory naukowe, jak i ideologiczne. W konkluzji pisał:

(...) poprzez badanie dziejów społeczno-gospodarczych, osiągniemy i rewizję naszej historii politycznej, zrewidujemy całość obrazu naszej przeszłości. Nowa Polska będzie wtedy mogła zobaczyć, poznać, zrozumieć przeszłość nie w oparach legendy szlacheckiej. Możemy być pewni, że będzie umiała z niej również wyciągnąć odpowiednie nauki'

6 „Kuźnica” 1945, nr 10. Przedruk W. Kula, Historia, zacofanie, rozwój, Warszawa 1983, s. 199-209. 
W 1947 r. W. Kula habilitował się na podstawie pracy Wstęp metodyczny do badań nad rozwojem spoleczno-gospodarczym Polski w XVI-XVIII wieku. Miał wtedy 31 lat. W tym samym roku pod szyldem ówczesnego Instytutu Pamięci Narodowej, kierowanym przez Stanisława Płoskiego, ukazała się jego książka Historia gospodarcza Polski w dobie popowstaniowej 1864-19187. Od 1949 r. W. Kula, jak wielu innych uczonych związanych w pierwszych latach powojennych z Łodzią, przeniósł się do Warszawy. Początkowo pracował jako docent, od 1950 r. profesor nadzwyczajny w Instytucie Historycznym UW. Od 1955 r. kierował Katedrą Historii Gospodarczej na Wydziale Ekonomicznym UW.

Przełom lat czterdziestych i pięćdziesiątych stał się dla wielu polskich historyków, w tym także dla W. Kuli, rodzajem intelektualnego i etycznego wyzwania. Jako człowiek lewicy, bohater niniejszego szkicu, znalazł się w sytuacji szczególnej ${ }^{8}$. Zetknięcie się z coraz bardziej totalitarną komunistyczną rzeczywistością musiało zrodzić rozczarowanie. W życiu naukowym kończył się czas dyskusji, wszechwładnie zaczęły dominować radzieckie wzory instytucjonalne i metodologiczne. W. Kula poddał się wielokrotnie opisywanej zasadzie dwójmyślenia99. Świadectwem jego niezgody na totalitarny eksperyment stały się pisane do szuflady Gusta ${ }^{10}$. Jednocześnie w ówczesnej działalności historyka nie brak przykładów jednoznacznego, deklarowanego oficjalnie, poparcia dla polityki władz.

Dotykamy w tym miejscu problemu odpowiedzialności polskich historyków, nie tylko i z pewnością nie przede wszystkim W. Kuli, za stalinowskie zniewolenie polskiej historiografii. Marcin Kula, komentując zebranie Marksistowskiego Zrzeszenia Historyków z 1950 r., stawia tezę, że ówcześni historycy „(...) nie zrozumieli, że nawet ewentualne słuszne postulaty metodologiczne w nowej

${ }^{7}$ Jej dopełnieniem, o czym warto pamiętać, było dzieło H. Wereszyckiego Historia polityczna Polski 1864-1918. O losach tej książki szerzej zob. R. Stobiecki, Henryk Wereszycki (1898-1990). Historyk w czasie próby, [w:] idem, Historycy polscy.... s. 95-126.

${ }^{8}$ Interesujący jest fakt, że mimo licznych zachęt, W. Kula nie zdecydował się na wstąpienie do partii. Pytany przez syna o motywy tej decyzji miał stwierdzić: „nie chcę składać dyskrecjonalnych opinii o kolegach”. Vide: M. Kula, Mimo wszystko bliżej Paryża niż Moskwy, Ksiązka o Francji, PRL i o nas historykach, Warszawa 2010, s. 104.

${ }^{9}$ Wiele nowych obserwacji na ten temat wnoszą listy publikowane przez M. Kulę we wspomnianym tomie Mimo wszystko... Dowiedzieć się z nich można sporo na temat relacji w środowisku historyków, panującej w nim hierarchii, tej rzeczywistej i tej narzucanej przez czynniki partyjne. Charakterystyczne dla małżeństwa Kulów i związanego z nimi kręgu przyjaciół i kolegów, są krytyczne uwagi na temat historyków blisko związanych z władzą (Henryk Jabłoński czy Żanna Kormanowa, np. s. 406, 414). W zderzeniu z oficjalnymi formami uczestnictwa w życiu naukowym i towarzyszących mu niezbędnych kompromisów, prywatne listy pozostają przykładem zawoalowanej i ukrytej postawy dystansu wobec polityki władz, wobec środowiska.

${ }^{10} \mathrm{Na}$ marginesie warto zaznaczyć, na co zwróciła uwagę A. Sosnowska, że w przypadku W. Kuli, a także zapewne wielu innych badaczy, mechanizm dwójmyślenia nie zniknął wraz z przełomem październikowym. Zdaniem A. Sosnowskiej, dowodnie świadczy o tym porównanie zapisów w Rozdziatkach i oficjalnie drukowanych tekstów W. Kuli. Eadem, Zrozumieć zacofanie. Spory historyków o Europę Wschodnia (1947-1990), Warszawa 2004, s. 115. 
epoce mogły się obrócić w swoje zaprzeczenie (mówiąc prościej w bezsens)"11. Wydaje się, że należałoby raczej napisać - nie chcieli zrozumieć. W ich świecie nie mieściły się inne intencje i inne motywacje, niż te, które kierowały nimi samymi. W. Kula reprezentował, jak sądzę, ten typ lewicowego intelektualisty, o którym po latach Krystyna Kersten pisała, że:

zamykał oczy i uszy, aby nie odbierać informacji o tym, co się dzieje w kraju, jak też używał całej potęgi swojego umysłu dla zbudowania gmachu racjonalizacji, akceptacji lub przynajmniej uległości wobec stanowionego porządku (...). Motorem tych operacji nie był konformizm, oportunizm, choć w konsekwencji prowadziły one do takich postaw. Gra toczyła się o coś więcej niż wygoda życia, stawką była przynależność, ceną przegranej - bezdomność ${ }^{12}$.

Rok 1956 oznaczał dla W. Kuli, podobnie jak dla większości środowiska historyków, cezurę niezwykle istotną, jedno z najważniejszych doświadczeń pokoleniowych. W „Kwartalniku Historycznym” opublikował tekst $W$ sprawie naszej polityki naukowej ${ }^{13}$. W intencji autora miał on zapoczątkować w środowisku historyków szerszą dyskusję nad zjawiskiem stalinizmu w historiografii polskiej $^{14}$.

Referat W. Kuli został poddany dyskusji na specjalnej naradzie w Instytucie Historii PAN, 26 czerwca 1956 r. Został on dobrze przyjęty przez środowisko. Poparcia jego tezom udzielili m.in.: Marian Małowist, Aleksander Gieysztor, Stefan Kieniewicz, Stanisław Śreniowski i, co ciekawe, Ż. Kormanowa ${ }^{15}$.

Druga połowa lat pięćdziesiątych i lata sześćdziesiąte to bez wątpienia najbardziej twórczy okres w biografii naukowej W. Kuli. Jeszcze w 1956 r. ukazały się Szkice o manufakturach w Polsce $w$ XVIII w., t. 1-2. W 1958 r. wyszły drukiem rozrachunkowe Rozważania o historii. Ciekawe, że autor do końca wahał się czy dołączyć do nich wspomniane Gusła ${ }^{16}$. Szczęśliwie, W. Kula nie posłuchał rad

${ }^{11}$ M. Kula, Mimo wszystko..., s. 457.

${ }^{12}$ K. Kersten, Bezdomny intelektualista w poszukiwaniu ratunku, [w:] eadem, Pisma rozproszone, red. T. Szarota, D. Libionka, Warszawa 2006, s. 20 (pierwodruk w piśmie „Odra” z 1990 r.).

13 „Kwartalnik Historyczny” 1956, R. LXIII, nr 3, s. 151-166.

${ }^{14}$ Szerzej piszę o tym w pracy Historiografia PRL. Zamiast podręcznika, Łódź 2020. W zbiorze tekstów źródłowych towarzyszących zasadniczej narracji, znalazł się wspomniany artykuł W. Kuli.

${ }^{15}$ Dyskusja nad obecnym stanem i możliwościami rozwojowymi naszej nauki historycznej, „Kwartalnik Historyczny” 1956, R. LXIII, nr 6, s. 72-87. Polemicznie do tekstu W. Kuli odnieśli się, ze skrajnie różnych punktów widzenia - S. Arnold i M.H. Serejski. Ten pierwszy zaprotestował przeciwko nazbyt krytycznej ocenie pierwszej połowy lat 50. Ten drugi z kolei zarzucił referentowi tendencję do „tuszowania” prawdziwych warunków rozwoju nauki historycznej w omawianym okresie, ibidem, s. 80-85.

${ }^{16} \mathrm{~W}$. Kula przed ich publikacją zwrócił się do bliskiego sobie grona badaczy z prośbą o lekturę i uwagi. W liście do żony pisał: „W dodatku te nieszczęsne «Gusła». Bronek chodzi o B. Geremka [dop. - R.S.], zdecydowanie przeciwny ich pomieszczeniu. Zgodność Labudy, Bronka i Krzysi [chodzi o K. Śreniowską - dop. - R.S.], trojga ludzi b. różnych, wartościowych i mnie życzliwych jest, przyznasz, niepokojąca. Nie umiem jej zlekceważyć - a wiem, że jeśli ich nie opublikuję, 
przyjaciół i dzięki temu otrzymaliśmy kompletną, choć nie pozbawioną ingerencji cenzury, wersję jednego z najciekawszych świadectw dokumentujących kwestię rozliczeń polskiej inteligencji z okresem stalinowskim ${ }^{17}$. Książka miała kilkanaście, w zdecydowanej większości wielce przychylnych recenzji i do dzisiaj należy do najbardziej cenionych w polskiej literaturze powojennej „traktatów metodologicznych"18.

W latach następnych ujrzały światło dzienne, przez wielu uważane za najbardziej wartościowe w dorobku W. Kuli, wspominana już - Teoria ekonomiczna ustroju feudalnego... (1962) oraz Problemy i metody historii gospodarczej (1963). Celem zasadniczym tej pierwszej było „zrozumienie wewnętrznych zasad funkcjonowania swoistej historycznej całości, jaką stanowił system folwarczno-pańszczyźniany w Polsce"19. Obok tego zagadnienia pojawia się inne, nie mniej istotne - problem przejścia od tego systemu do kapitalizmu. Zdaniem ucznia - Jacka Kochanowicza - zaproponowana przez W. Kulę koncepcja rozwijała się dwoma równoległymi torami. Pierwszy z nich, to prowadzone ponad dwadzieścia lat badania nad polskimi manufakturami, drugi, to studia nad historią gospodarczą jako odrębną dyscypliną badawczą i jej związkami z innymi naukami społecznymi. W opinii tego historyka novum podejścia zastosowanego przez W. Kulę polegało na połączeniu w tym dziele metody „empirycznego badania mikroekonomicznego" $\mathrm{z}$,modelową analizą typu makro" ${ }^{20}$. Podobnie ujął to jeden $\mathrm{z}$ recenzentów, który napisał, że „Kula-ekonomista formułuje trafne pytania, na które odpowiada Kula-historyk" ${ }^{21}$.

W kolejnych latach W. Kula zapoczątkował i patronował badaniom nad strukturami społecznymi w Polsce, których podsumowaniem była książka Przemiany społeczne w Królestwie Polskim 1815-1864 wydana w 1979 r. pod redakcją W. Kuli i Janiny Leskiewiczowej. Ta ostatnia w następujący sposób charakteryzowała ten pionierski na polskim gruncie program badawczy:

Punktem wyjściowym był dla nas problem rozpadu podziałów stanowych. Szukaliśmy więc odpowiedzi na pytania o wewnętrzne przemiany jakim ulegały feudalne stany, o siłę i trwałość stanowych więzi, o dziedziczenie czy też pokoleniowe zmiany pozycji społecznych $^{22}$.

to będę miał do siebie wieczny żal i poczucie tchórzostwa" (list W. Kuli z 15.09.1957). Cyt. za: M. Kula, Mimo wszystko..., s. 516-517. Sprawa ta wracała także w kolejnych listach między małżonkami, ibidem, s. 517-520, 594.

${ }^{17} \mathrm{Na}$ temat ingerencji cenzury w tekst W. Kuli pisał Z. Romek w pracy Cenzura a nauka historyczna w Polsce 1944-1970, Warszawa 2010, s. 216-218.

${ }_{18}$ Zestawienie recenzji, W. Kula, Rozdziatki..., s. 471.

${ }^{19}$ W. Kula, Teoria ekonomiczna ustroju feudalnego, wyd. II, Warszawa 1983, s. 5.

${ }^{20}$ J. Kochanowicz, Witold Kula i badania przedkapitalistycznych systemów gospodarczych, [w:] Dziedzictwo Witolda Kuli, Warszawa 1990, s. 152.

${ }_{21}$ I. Sachs, Model historii, „Przegląd Kulturalny” 8 V 1963.

22 J. Leskiewiczowa, Idea i program historii struktur spolecznych, [w:] Dziedzictwo..., s. 188. 
Wcześniej ukazały się dwie inne ważne jego prace Miary i ludzie (1970), studium $\mathrm{z}$ antropologicznie pojmowanej metrologii historycznej oraz obszerny wstęp do edycji Listów emigrantów z Brazylii i Stanów Zjednoczonych 1890-1891 wydanych przez W. Kulę, Ninę Assorodobraj-Kulę i M. Kulę (1973). $\mathrm{O}$ tej pierwszej tak pisał po latach jego syn Marcin:

\begin{abstract}
jakby to zaskakująco nie brzmiało, do współczesności odnosiło się również Ojca zainteresowanie historią miar. Długo traktował je jako hobby, nawet zbierał jakieś dawne odważniki, wagi i miarki. Skończyło się wszakże owo hobby napisaniem książki. Nie jest ona studium z klasycznej historii miar, gdzie podstawowe są ich spisy i ekwiwalencje. Pamiętam jak Ojciec, w odpowiedzi na prośbę opracowania czegoś w takim stylu do serii nauk pomocniczych historii, uśmiechnął się, że chyba nigdy tego nie zrobi - choć zapewne nie negował, bo trudno negować, potrzeby istnienia takich zestawień. Książka Ojca jest poświęcona wprowadzeniu i rozprzestrzenianiu się systemu metrycznego, ale jej intelektualny problem jest znacznie szerszy. Autor pyta jak mianowicie powstaje potrzeba nowego rozwiązania, jak ludzie do niego dochodzą intelektualnie, tworzą je całkowicie z głowy (z głowy uwarunkowanej przez epokę!) i jak wprowadzają je w życie. Stawia pytanie jak jest uwarunkowane funkcjonowanie tego rozwiązania i jak ono ewoluuje pod wpływem zmieniających się czynników społecznych - zaś, ostatecznie, jak ono nad ludźmi zapanowuje, choć ewoluując ${ }^{23}$.
\end{abstract}

Z kolei na wspomniany zbiór korespondencji W. Kula natknął się w archiwum jeszcze w czasie wojny. Kolekcja w większości spłonęła w Powstaniu Warszawskim. Uratowało się ok. 300 listów, które stały się podstawą wspomnianego wydawnictwa.

Od lat sześćdziesiątych, W. Kula cieszył się coraz większym uznaniem poza granicami Polski. Aktywności twórczej towarzyszyły liczne podróże naukowe. W latach 1963-1964 i 1971-1972 W. Kula był wykładowcą w paryskiej École Pratique des Hautes Etudes, ponadto wykładał także we Włoszech, Szwajcarii i Czechosłowacji. Był współorganizatorem pierwszych kongresów historii gospodarczej, w latach 1968-1970 kierował Międzynarodowym Stowarzyszeniem Historii Gospodarczej, potem został jej honorowym przewodniczącym. $\mathrm{Z}$ czasem doceniono go także $\mathrm{w}$ kraju i w środowiskach polskich na emigracji - został najpierw członkiem korespondentem (1979), a następnie członkiem rzeczywistym PAN (1986). W 1974 r. otrzymał nagrodę im. A. Jurzykowskiego.

Lata sześćdziesiąte przynoszą znaczącą ewolucję jego poglądów politycznych. Coraz wyraźniejsze były związki W. Kuli z tzw. warszawską szkołą historyków idei, m.in. z Bronisławem Baczką, Leszkiem Kołakowskim. W. Kula uczestniczył w nieformalnym seminarium na którym spotykali się ówcześni „rewizjoniści”24.

${ }^{23}$ M. Kula, Historia nie dzieli się na „dawniej” i „dziš” „Kultura i Społeczeństwo” 2013, nr 3, s. 220. Jest to referat wygłoszony przez M. Kulę na konferencji „Polska szkoła socjologii historycznej i historii gospodarczej: Witold Kula, Marian Małowist".

${ }^{24}$ Poza wymienionymi do tego grona należeli m.in.: Janina Zakrzewska, Nina Assorodobraj-Kula, Paweł Beylin, Włodzimierz Brus, Ryszard Herczyński, Tadeusz Kowalik, Kazimierz Łaski, 
Narastający krytycyzm wobec władzy, a także utratę wiary w sensowną ewolucję systemu, potwierdzają zapiski w Rozdziałkach ${ }^{25}$.

W połowie lat siedemdziesiątych postępująca choroba nie pozwoliła historykowi na aktywne uczestniczenie w życiu naukowym i publicznym. W sierpniu 1980 r. podpisał wraz z żoną - Niną Assorodobraj-Kulą „Apel 64”, będącym głosem popierającym żądania strajkujących robotników. W 1986 r. przeszedł na emeryturę. Zmarł 12 lutego 1988 r. w Warszawie.

$\mathrm{Na}$ koniec warto postawić pytanie o dziedzictwo W. Kuli. W jakim stopniu podejmowane przezeń tematy badawcze były (są) kontynuowane? Czy kreowana przez niego wizja historii znalazła swoich naśladowców?

Wnioski jakie mi się nasuwają nie są optymistyczne, choć zapewne kwestia ta wymagałaby bardziej szczegółowych badańn ${ }^{26}$. Od czasu do czasu pod egidą, co charakterystyczne Polskiego Towarzystwa Ekonomicznego, odbywają się konferencje poświęcone postaci i dorobkowi W. Kuli. W związku z tym należy wspomnieć o spotkaniu z 2013 r. w Warszawie. Jego tytuł brzmiał „Polska szkoła socjologii historycznej i historii gospodarczej: Witold Kula, Marian Małowist”. Referaty wygłosili wówczas m.in.: syn Marcin, Henryk Szlajfer, Anna Sosnowska-Jordanovska, Zbigniew M. Kowalewski, Jan Sowa i Andrzej W. Nowak ${ }^{27}$. Trzy lat później, w stulecie urodzin W. Kuli, zorganizowano konferencję „Czy historia gospodarcza się przeżyła?"28.

Wydaje się, że po śmierci dwóch wybitnych uczniów Kuli - Jerzego Jedlickiego i Jacka Kochanowicza, bliska mu, historia społeczno-gospodarcza przeżywa pewien kryzys. Brakuje prac, które wyrastałyby z interdyscyplinarnej perspektywy, poruszały tematy ważne nie tylko z punktu widzenia historii Polski, śmiało mierzyłyby się z coraz silniejszym nurtem narodowej megalomanii. $\mathrm{Z}$ tego powodu dobrze się stało, że znana czytelnikowi polskiemu praca

Jerzy Szacki. Nazwę Seminarium Kultury Politycznej zaproponował Stefan Żółkiewski, ówczesny sekretarz Wydziału I PAN, a nieregularne spotkania odbywały się w jego gabinecie. Wspomina o tym m.in. K. Pomian w rozmowie z M. Bajer, Blizny po ukąszeniu, Warszawa 2005, s. 154-155. Vide także: J. Eisler, Marzec 1968. Geneza. Przebieg. Konsekwencje, Warszawa 1991, s. 315. Zdaniem tego ostatniego zostało ono utworzone najprawdopodobniej na przełomie 1964 i 1965 r.

${ }^{25}$ W. Kula, Rozdziatki, do druku podali N. Assorodobraj-Kula, M. Kula, Warszawa 1996 (ibidem obszerna bibliografia dotycząca wspomnień o W. Kuli i omówień jego twórczości zestawiona przez M. Kulę, s. 489-493).

${ }^{26}$ Podobną tezę postawił M. Kula pisząc, że dorobek Ojca ,jest stosunkowo mało obecny w polskim środowisku historycznym. Idem, Historia nie dzieli się... Na podstawie sondy w Google Scholar można stwierdzić, że w przypadku pracy Problemy i metody historii gospodarczej, suma wszystkich wzmianek (cytowań) to ok. 180 pozycji. Przy czym jeśli zawęzimy je do okresu PRL to daje 64 pozycje, czyli 1/3 całości. Jeśli chodzi o książkę Miary i ludzie (Measures and Men) Google Scholar odnotował 443 cytowania (za dwa wydania z 1986 i reedycję z 2014).

${ }^{27} \mathrm{http} / / /$ www.pte.pl/pliki/2/1/Konferencja\%2011.06.2013.pdf (dostęp: 13.01.2021).

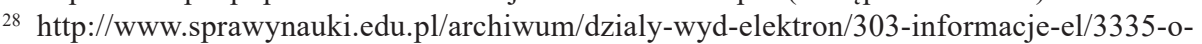
historii-gospodarczej-w-pte (dostęp: 13.01.2021). Dostępny jest jej zapis na kanale youtube. 
A. Sosnowskiej, której jednym z bohaterów jest W. Kula, ukazała się ostatnio w języku angielskim. Być może, odegra ona jednak pewną rolę w przypomnieniu międzynarodowej społeczności badaczy, polskiego wkładu w debatę dotyczącą gospodarczego zacofania Europy Wschodniej ${ }^{29}$.

Podobnie rzecz wygląda w przypadku tego fragmentu twórczości W. Kuli, która mieści się w nurcie antropologii kulturowej. Poza synem Marcinem, nie widać innych historyków, którzy szliby tą drogą, próbowali badać kulturowe wytwory pracy człowieka, życie codzienne widziane z perspektywy np. tytułowych miar i wag ${ }^{30}$. Propozycja W. Kuli od czasu do czasu pojawia się w studiach metodologiczno-historiograficznych, ale najczęściej nie znajduje kontynuacji w praktyce dziejopisarskiej ${ }^{31}$.

We współczesnej historiografii polskiej brakuje także „traktatów metodologicznych", nawiązujących do Rozważań o historii, przykładu refleksji nad przeszłością skierowanej nie tylko do wąskiego grona specjalistów, ale do szerszej publiczności.

Żeby jednak obraz nie wypadł tak czarno, to dodam na koniec, że na tym tle zaskakuje dość intensywna, choć nieporównywalna z dorobkiem M. Małowista, recepcja dzieł W. Kuli, przede wszystkim jego Teorii ekonomicznej ustroju feudalnego, w obrębie studiów postkolonialnych czy historii globalnej. Jak pisze czołowa reprezentantka tych pierwszych - Leela Gandhi - dyscyplina ta zmierza do ,zreformowania intelektualnych i epistemologicznych wykluczeń zachodniej akademii i stwarza przebywającym na Zachodzie niezachodnim krytykom możność prezentowania własnego dziedzictwa kulturowego jako wiedzy"32. Książka

${ }^{29}$ A. Sosnowska, Explaining Economic Backwardness. Post-1945 Polish Historians on Eastern Europe, CEU Press, Budapest-New York 2019.

${ }^{30}$ Warto w tym miejscu przywołać m.in. następujące prace M. Kuli: Zegarek historyka, Warszawa 2001 i Krótki raport o użytkowaniu historii, Warszawa 2004. Ciekawą próbą zaadoptowania koncepcji W. Kuli do badań z zakresu ekonomii podjął A.W. Nowak, Czy możliwa jest metrologiczna suwerenność? Metrologia i ekonomia polityczna miary, „Przegląd Humanistyczny” 2014, $\mathrm{nr}$ 5, s. 19-32. Vide także inne teksty w tym numerze poświęcone perspektywie postkolonialnej w humanistyce. Na temat recepcji „Miar i ludzi” w historiografii zachodniej pisała ostatnio A. Echterholter, Quantification as Conflict. Witold Kula's Political Metrology and Its Reception in the West, „Historyka” 2019, t. 49, s. 117-141.

${ }^{31}$ Vide np. W. Piasek, Notatki z etnografii myśli wspótczesnej $w$ dziedzinie historii. Informacje etnograficzne, diagnozy, wielkie kwestie, Torun 2019. Autor ten wcześniej poświęcił twórczości W. Kuli książkę, Antropologizowanie historii. Studium metodologiczne twórczości Witolda Kuli, Poznań 2004, angielska wersja Anthropologising History: a Historiografic and Methodoligical Case Study of Witold Kula, Torun 2018.

${ }^{32}$ L. Gandhi, Teoria postkolonialna, tłum. J. Serwański, posłowie E. Domańska, Poznań 2008. Praca zawiera zestawioną przez E. Domańską pomocną bibliografię dotyczącą studiów postkolonialnych. Z późniejszych polskich prac na ten temat vide np.: Perspektywy postkolonializmu $w$ Polsce. Polska w perspektywie postkolonialnej, „Debaty Artes Liberales” 2016, t. X, red. J. Kieniewicz; Humanistyka (pót)peryferii, red. K. Abriszewski, A.F. Kola, J. Kowalewski, Olsztyn 2016. 
W. Kuli pojawia się w tym rozważaniach w kontekście podejmowanej przez badaczki i badaczy analizy odrębnych dróg rozwoju gospodarczego, odmiennych od Zachodu, przede wszystkim w odniesieniu do tzw. krajów Trzeciego Świata. W Polsce rodzące się dopiero studia postkolonialne raczej nie są domeną historyków. Do dokonań W. Kuli odwołują się zatem przedstawiciele innych nauk humanistycznych m.in. Jan Sowa czy Tomasz Zarycki ${ }^{33}$.

$\mathrm{W}$ tej sytuacji wydanie w łódzkim periodyku zapomnianej pracy magisterskiej W. Kuli, wydaje mi się przedsięwzięciem zasługującym na pochwałę. Nie tylko z powodów jej walorów poznawczych i źródłowych, o których pisze Jarosław Kita w tekście Od Redakcji. Także dlatego, że dzięki temu mamy unikalną szansę odkryć na nowo fragment dziedzictwa młodego historyka, zapoznać się z kulisami jego warsztatu i być może inaczej spojrzeć na jego późniejsze wielkie dokonania.

\section{BIBLIOGRAFIA}

„Kuźnica” 1945, nr 10.

„Kwartalnik Historyczny” 1956, R. LXIII, nr 3.

Blackwood L., Witold Kula 1916-1988, [w:] Encyklopedia of Historians and Historical Writing, ed. K. Boyd, London-Chicago 1999, s. 670.

Dyskusja nad obecnym stanem i możliwościami rozwojowymi naszej nauki historycznej, „Kwartalnik Historyczny" 1956, R. LXIII, nr 6, s. 72-87.

Dziedzictwo Witolda Kuli, Warszawa 1990.

Eisler J., Marzec 1968. Geneza. Przebieg. Konsekwencje, Warszawa 1991.

Gandhi L., Teoria postkolonialna, tłum. J. Serwański, posłowie E. Domańska, Poznań 2008.

Górny M., Historical Writing in Poland, Czechoslovakia, and Hungary, [w:] The Oxford History of Historical Writing, eds. by A. Schneider and D. Woolf, vol. 5, Oxford 2015, s. 243-265.

Humanistyka (pót)peryferii, red. K. Abriszewski, A.F. Kola, J. Kowalewski, Olsztyn 2016.

Kersten K., Bezdomny intelektualista w poszukiwaniu ratunku, [w:] K. Kersten, Pisma rozproszone, red. T. Szarota, D. Libionka, Warszawa 2006, s. 20 (pierwodruk w piśmie „Odra” z 1990 r.).

Kochanowicz J., Witold Kula i badania przedkapitalistycznych systemów gospodarczych, [w:] Dziedzictwo Witolda Kuli, Warszawa 1990.

Kula M., Historia nie dzieli się na „dawniej” i „dziś”, „Kultura i Społeczeństwo” 2013, nr 3.

T. Siewierski, Marian Małowist i krag jego uczniów. Z dziejów historiografii gospodarczej, Warszawa 2016; Odwołania do W. Kuli znaleźć można także C. Radding, Landscapes of Power and Identity: Comparative Histories in the Sonoran Desert and Forests of Amazonia from Colony To Republic, Durham-London 2005. A. Pufelska, The Transition from Feudalism to Capitalism and the Problem of Temporalization - on the 100 th Anniversary of Witold Kula's Birth, [w:] Filosophy of Globalization, ed. by C. Roldan, D. Brauer, J. Rohbeck, Berlin-Boston 2018, s. 287-300 i w innych tekstach tego tomu.

33 J. Sowa, Fantomowe ciało króla. Peryferyjne zmagania z nowoczesna forma, Kraków 2011; T. Zarycki, Peryferie. Nowe ujęcia zależności centro-peryferyjnych, Warszawa 2010. 
Kula M., Jerzy Jedlicki historyk nietypowy, Warszawa 2018.

Kula M., Krótki raport o użytkowaniu historii, Warszawa 2004.

Kula M., Mimo wszystko bliżej Paryża niż Moskwy, Książka o Francji, PRL i o nas historykach, Warszawa 2010.

Kula M., Zegarek historyka, Warszawa 2001.

Kula W., Historia, zacofanie, rozwój, Warszawa 1983.

Kula W., Moja edukacja sentymentalna, [w:] W. Kula, Wokót historii, Warszawa 1988.

Kula W., Rozdziałki, do druku podali N. Assorodobraj-Kula, M. Kula, Warszawa 1996.

Kula W., Teoria ekonomiczna ustroju feudalnego, wyd. II, Warszawa 1983.

Leskiewiczowa J., Idea i program historii struktur społecznych, [w:] Dziedzictwo Witolda Kuli, Warszawa 1990, s. 188.

Nowak A.W., Czy możliwa jest metrologiczna suwerenność? Metrologia i ekonomia polityczna miary, „Przegląd Humanistyczny” 2014, nr 5, s. 19-32.

Perspektywy postkolonializmu w Polsce. Polska w perspektywie postkolonialnej, „Debaty Artes Liberales" 2016, t. X, red. J. Kieniewicz.

Piasek W., Anthropologising History: a Historiografic and Methodoligical Case Study of Witold Kula, Toruń 2018.

Piasek W., Antropologizowanie historii. Studium metodologiczne twórczości Witolda Kuli, Poznań 2004.

Piasek W., Notatki z etnografii myśli współczesnej w dziedzinie historii. Informacje etnograficzne, diagnozy, wielkie kwestie, Toruń 2019.

Pufelska A., The Transition from Feudalism to Capitalism and the Problem of Temporalization - on the 100 th Anniversary of Witold Kula's Birth, [w:] Filosophy of Globalization, eds. by C. Roldan, D. Brauer, J. Rohbeck, Berlin-Boston 2018, s. 287-300.

Radding C., Landscapes of Power and Identity: Comparative Histories in the Sonoran Desert and Forests of Amazonia from Colony To Republic, Durham-London 2005.

Romek Z., Cenzura a nauka historyczna w Polsce 1944-1970, Warszawa 2010.

Sachs I., Model historii, „Przegląd Kulturalny”, 8 V 1963.

Siewierski T., Marian Małowist i krąg jego uczniów. Z dziejów historiografii gospodarczej, Warszawa 2016.

Sosnowska A., Explaining Economic Backwardness. Post-1945 Polish Historians on Eastern Europe, CEU Press, Budapest-New York 2019.

Sosnowska A., Zrozumieć zacofanie. Spory historyków o Europę Wschodnia (1947-1990), Warszawa 2004.

Sowa J., Fantomowe ciało króla. Peryferyjne zmagania z nowoczesna forma, Kraków 2011.

Stobiecki R., Henryk Wereszycki (1898-1990). Historyk w czasie próby, [w:] R. Stobiecki, Historycy polscy wobec wyzwań XX wieku, Poznań 2014, s. 95-126.

Stobiecki R., Historiografia PRL. Zamiast podręcznika, Łódź 2020.

Stobiecki R., Witold Kula (1916-1988). Historyk zaplatany w historię, [w:] R. Stobiecki, Historycy polscy wobec wyzwań XX wieku, Poznań 2014, s. 273-306.

Wereszycki H., Historia polityczna Polski 1864-1918, Wrocław 1990.

Zarycki T., Peryferie. Nowe ujęcia zależności centro-peryferyjnych, Warszawa 2010.

http://www.pte.pl/pliki/2/1/Konferencja\%2011.06.2013.pdf (dostęp: 13.01.2021).

http://www.sprawynauki.edu.pl/archiwum/dzialy-wyd-elektron/303-informacje-el/3335-ohistorii-gospodarczej-w-pte (dostęp: 13.01.2021). 


\section{Rafat Stobiecki}

(University of Lodz)

\section{WITOLD KULA (1916-1988). SKETCH FOR A PORTRAIT}

W

itold Kula undoubtedly belongs to the narrow elite of historians of the era of the People's Republic of Poland, he is also its most recognized representative in the international arena. This text aims at presenting the most important moments of his biography, a brief characteristic of his achievements and his reception in contemporary historiography.

Keywords: professor Witold Kula, $20^{\text {th }}$ century, an outline of a biography, reception of scientific achievements 